\title{
Autophagy in Protein and Organelle Turnover
}

\author{
N. Mizushima \\ Department of Physiology and Cell Biology, Tokyo Medical and Dental University, \\ 1-5-45 Yushima, Bunkyo-ku, Tokyo 113-8519, Japan \\ Correspondence: nmizu.phy2@tmd.ac.jp
}

\begin{abstract}
Macroautophagy is an evolutionarily conserved degradation system in the cell. In autophagy, intracellular components are sequestered by autophagosomes and subsequently degraded upon fusion with lysosomes. Genetic analysis of autophagy in mammals has revealed that autophagy is important for various physiological processes, such as adaptive responses to starvation, embryogenesis, quality control of intracellular proteins and organelles, tumor suppression, degradation of intracellular pathogens, and anti-aging. In this review I describe the various roles of autophagy, with a particular focus on the turnover of cytoplasmic proteins and organelles.
\end{abstract}

Autophagy is a process in which cytoplasmic components are degraded by the lysosome (Mizushima 2007; Levine and Kroemer 2008). Both macromolecules, such as proteins, glycogens, lipids, and nucleotides and organelles such as mitochondria, peroxisomes, and the endoplasmic reticulum, can be degraded by autophagy. There are three types of autophagy: macroautophagy, microautophagy, and chaperone-mediated autophagy. Microautophagy involves inward invagination of the lysosomal membrane to take up small portions of the cytoplasm. In chaperone-mediated autophagy, substrate proteins are selectively recognized by cytoplasmic chaperons and directly delivered to the lysosomal lumen across the lysosomal membrane.

Macroautophagy, which will be simply referred to here as autophagy, is mediated by the autophagosome (Fig. 1). A small portion of the cytoplasm is engulfed by an isolation membrane/phagophore, leading to formation of a double-membrane autophagosome. The outer membrane of the autophagosome fuses with the lysosome, and materials inside the autophagosome are degraded by lysosomal hydrolases. Genetic studies in yeast have identified more than 30 autophagy-related $(A T G)$ genes, which are required for various types of autophagy (Suzuki and Ohsumi 2007; Xie and Klionsky 2007). Many of these $A T G$ genes are conserved in higher eukaryotes (Longatti and Tooze 2009). Reverse genetic approaches performed in various organisms, including mice, have revealed the pleiotropic roles of autophagy. These functions include maintenance of the amino acid pool during starvation and preimplantation embryo development, intracellular quality control, tumor suppression, antigen presentation, and killing of intracellular microorganisms (Rubinsztein 2006; Cecconi and Levine 2008; Mizushima et al. 2008; Mizushima and Levine 2010; Levine et al. 2011). This chapter focuses on the role of autophagy in protein metabolism and organelle turnover.

\section{ADAPTATION TO STARVATION}

The most fundamental and evolutionarily conserved role of autophagy is the adaptation response to starvation conditions. In nutrient-rich conditions, autophagy is suppressed at the basal level. However, when cells and even whole organisms are subjected to starvation, autophagy is upregulated (Tsukada and Ohsumi 1993; Kuma et al. 2004). Starvation-induced autophagy is important for maintaining the amino acid pool inside cells. For example, the level of amino acids in autophagy-deficient yeast cells is lower than that in wild-type cells under starvation (Onodera and Ohsumi 2005). These autophagy-derived amino acids are important for protein synthesis. In starved wild-type yeast cells, expression levels of certain proteins, including enzymes involved in amino acid biosynthetic pathways, vacuolar enzymes, mitochondrial respiration proteins, and reactive oxygen species (ROS) scavenger proteins, are increased (Onodera and Ohsumi 2005; Suzuki et al. 2011). Induction of these proteins is highly dependent on autophagy under nitrogen-starvation conditions. Induction of ROS scavengers is particularly important because ROS accumulation in autophagydeficient yeast cells leads to starvation-induced cell death (Suzuki et al. 2011).

Neonates face severe starvation until nutrients are supplied by milk feeding. Accordingly, autophagy is actively induced during the neonatal period (Kuma et al. 2004). Neonatal autophagy is indeed important for maintenance of the amino acid pool, as evidenced by the fact that amino acid levels in mice deficient in genes essential for autophagosome formation, such as $A T G 3$ (Sou et al. 2008), ATG5 (Kuma et al. 2004), and Atg7 (Komatsu et al. 2005), are $30 \%-40 \%$ lower than those in wild-type neonatal mice at $10 \mathrm{~h}$ after birth, even though the levels are normal at birth. As these neonates show activation of AMP-activated protein kinase, autophagy-derived amino acids could also be utilized for energy production 


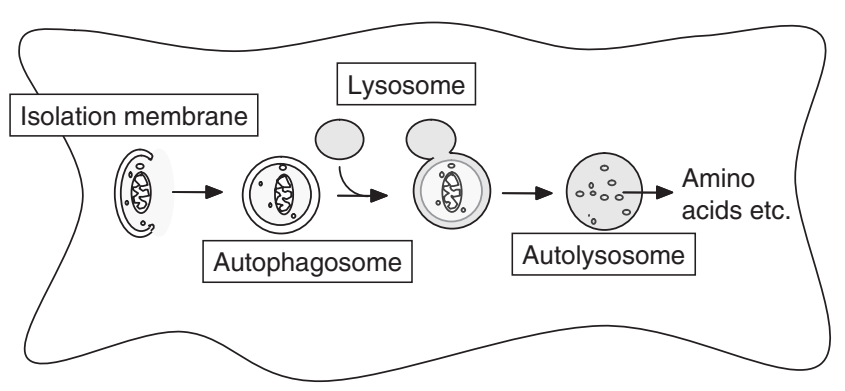

Figure 1. The process of autophagy in mammalian cells. A portion of cytoplasm, including organelles, is enclosed by an isolation membrane (or phagophore) to form an autophagosome. The outer membrane of the autophagosome fuses with the lysosome, and the internal material is degraded.
(Kuma et al. 2004). However, the precise mechanism of the neonatal lethality remains unknown; such neonates show additional abnormal phenotypes such as suckling defects, which eventually lead to neonatal death.

\section{OOCYTE-TO-EMBRYO TRANSITION}

Autophagy is also extensively induced by fertilization in mice (Tsukamoto et al. 2008). This observation is apparently contradictory to previous results using systemic Atg5- and Atg7-deficient mice because these mice can survive throughout embryogenesis, although they die after birth (Kuma et al. 2004; Komatsu et al. 2005). However, we realized that $A \operatorname{tg} 5^{-}$oocytes (lacking the ATG5 gene) derived from Atg $5^{+/-}$female mice contain maternally inherited Atg 5 proteins in the cytoplasm, which can rescue the autophagy-deficient phenotype of conventional $\operatorname{Atg} 5^{-/-}$mice during early embryogenesis. We subsequently generated oocyte-specific Atg $^{-/-}$ mice to produce a complete autophagy-deficient mouse during early embryogenesis (Tsukamoto et al. 2008). The obtained embryos showed developmental arrest at the four- to eight-cell stages, and showed reduced rates of protein synthesis. We speculate that autophagy should be important for providing essential amino acids for embryonic protein synthesis until implantation. As $\operatorname{Atg} 5^{-1-}$ mice can survive embryogenesis, it appears that autophagy is not essential for later developmental processes (Tsukamoto et al. 2008).

\section{PROTEIN QUALITY CONTROL BY AUTOPHAGY}

Although drastic induction is a characteristic feature of autophagy, it also occurs constitutively at low basal levels. This "basal autophagy" is important for intracellular quality control, particularly in the nervous system and liver. Komatsu and coworkers demonstrated that mice with liver-specific deletion of $A T G 7$ develop severe hepatomegaly with intracellular accumulation of ubiquitinpositive aggregates and deformed organelles (Komatsu et al. 2005).

Similar findings were also observed in mice with neural cell-specific deletion of either ATG7 (Atg $7^{\text {flox/flox }}$;Nestin-Cre; Komatsu et al. 2006) or ATG5 (Atg5 flox/flox;Nestin-Cre; Hara et al. 2006). These mice develop progressive motor deficits such as ataxic gait, impaired motor coordination, abnormal limb clasping reflexes, and systemic tremor, and sporadic deaths occur after 3 weeks of age in some populations. Axonal swelling and partial loss of Purkinje cells and cerebral pyramidal cells are induced. As in liver-specific knockout mice, neurons of Atg $5^{\text {flox/flox }}$;Nestin-Cre and Atgfflox/flox ;Nestin-Cre mice demonstrate ubiquitinpositive protein aggregates. Furthermore, even neonates of systemic Atg5 knockout mice possess ubiquitinpositive aggregates in many neonatal tissues such as hepatocytes, a subset of neurons, the anterior lobe of the pituitary gland, and the adrenal gland (Hara et al. 2006). Thus, autophagy is critical for intracellular clearance, even if no disease-associated aggregate-prone proteins are expressed.

\section{SELECTIVE DEGRADATION OF p62 BY AUTOPHAGY}

Although the majority of autophagy substrates are nonselectively incorporated into the autophagosome, the autophagosomal membrane can selectively recognize some specific proteins and organelles (Fig. 2) (Kirkin et al. 2009; Kraft et al. 2010). The best known selective substrate for autophagy in mammals is p62/SQSTM1 (Bjørkøy et al. 2005; Pankiv et al. 2007). p62 has multiple functions in bone remodeling, inclusion body formation, obesity, and inflammatory signal transduction (Wooten et al. 2006; Seibenhener et al. 2007; Moscat and Diaz-Meco 2009). p62 has a short motif (WXXL-like) that interacts with microtubule-associated protein 1 light chain 3 (LC3), an autophagosomal protein, and therefore is incorporated inside the autophagosome and degraded. Indeed p62 accumulates in autophagy-deficient tissues and cells and forms intracellular aggregates (Bjørkøy et al. 2005; Komatsu et al. 2007).

Degradation of p62 by autophagy is physiologically important. When p62 is simultaneously deleted in liverand brain-specific Atg7 knockout mice, formation of ubiquitin-positive aggregates is suppressed (Komatsu et al. 2007). Accordingly, the abnormal liver phenotype including hepatomegaly and liver dysfunction is dramatically improved in $\operatorname{Atg} 7^{-/-} p 62^{-/-}$double knockout mice (Komatsu et al. 2007). Why is p62 cytotoxic in the liver? p62 interacts with Keap1, a component of ubiquitin ligase that induces proteasomal degradation of the transcription factor Nrf2. p62 overexpression sequesters Keap1, and thereby inhibits Nrf2 degradation (Komatsu et al. 2010; Lau et al. 2010). Stabilized Nrf2 activates 

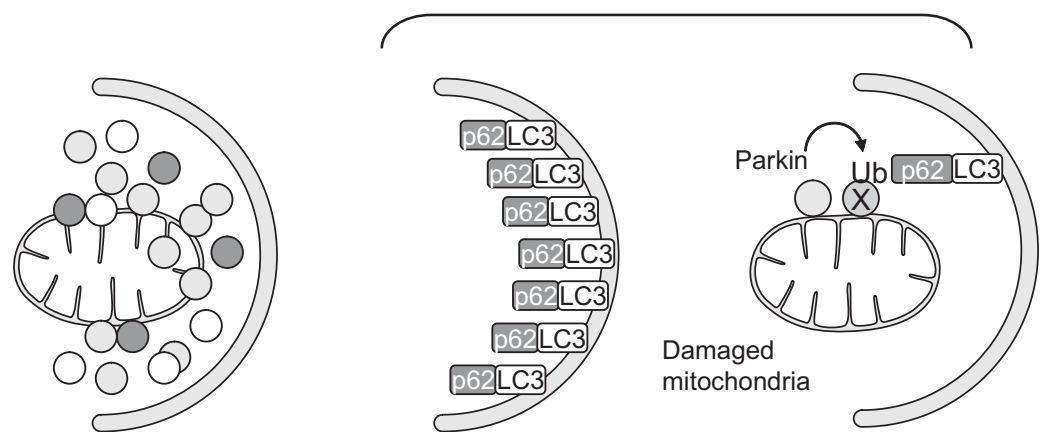

Figure 2. Selective autophagy. (A) Most autophagic substrates can be nonselectively engulfed by the autophagosome. (B) p62 and other selective substrates have the Atg8/LC3 interacting motif and are recognized by autophagosomal membranes for preferential degradation (left). Depolarized mitochondria can also be selectively degraded by autophagy, although it remains unknown how mitochondria are recognized (right). Ub, polyubiquitin chain.

its target genes, such as those of antioxidant proteins and detoxification enzymes, and paradoxically causes liver damage. This idea is supported by evidence that shows that liver damage in Atg 7 knockout mice can be ameliorated by deletion of $\mathrm{Nrf} 2$ and further exacerbated by deletion of Keapl (Komatsu et al. 2010).

In contrast to liver, neurological symptoms of neural cell-specific Atg7 knockout mice are not improved by deletion of p62, even though ubiquitin-positive aggregates are absent (Komatsu et al. 2007). Therefore, formation of the inclusion body itself may not be toxic, and autophagy probably plays a more general role in intracellular quality control, not only for turnover of p62.

It has also been hypothesized that p62 functions as an adaptor (or cargo receptor) for ubiquitinated proteins, because of its ubiquitin-associated (UBA) domain (Kim et al. 2008; Kirkin et al. 2009). However, this model has not been experimentally proved in mouse models. Deletion of p62 in $\operatorname{Atg} 7$ knockout mice does not significantly reduce the amount of ubiquitinated proteins (Komatsu et al. 2010). It has also recently been suggested that accumulation of ubiquitinated proteins in autophagydeficient hepatocytes and neurons could be a secondary consequence of Nrf2 activation, rather than a direct result of a defect in the clearance of ubiquitinated proteins (Riley et al. 2010). Finally, the results of a recent in vitro study also suggest that ubiquitinated proteins are not degraded by autophagy (Myeku and Figueiredo-Pereira 2011). The "p62 adaptor hypothesis" needs to be further evaluated in more physiological settings.

\section{QUALITY CONTROL OF MITOCHONDRIA BY AUTOPHAGY: IMPLICATIONS FOR THE PATHOGENESIS OF PARKINSON'S DISEASE}

In contrast to the ubiquitin-proteasome system, autophagy can degrade entire organelles such as mitochondria, peroxisomes, and the endoplasmic reticulum. Autophagic degradation of mitochondria, termed mitophagy, is currently attracting attention because of its potential role in the pathogenesis of Parkinson's disease (PD). PD is one of the most common neurological diseases and is primarily caused by a loss of dopaminergic neurons in the substantia nigra. Many PD-related genes have been identified from patients with familial PD (Abou-Sleiman et al. 2006; Zhu and Chu 2010). One of these genes codes for Parkin, an E3 ubiquitin ligase (Kitada et al. 1998). Recent studies have revealed that Parkin is important for elimination of damaged mitochondria by autophagy (Youle and Narendra 2011). Parkin translocates from the cytosol to depolarized mitochondria, and triggers mitophagy (Narendra et al. 2008) (Fig. 2). Targeting of Parkin to mitochondria is dependent on PTEN-induced putative kinase 1 (PINK1), another PD-associated gene product (Gegg et al. 2010; Geisler et al. 2010; Kawajiri et al. 2010; Matsuda et al. 2010; Narendra et al. 2010a; Rakovic et al. 2010; Vives-Bauza et al. 2010; Ziviani et al. 2010).

However, the detailed mechanism underlying Parkinmediated mitophagy remains to be elucidated. Several mitochondrial proteins such as voltage-dependent anion channel 1 (VDAC1) (Geisler et al. 2010), mitofusin (a mitochondrial pro-fusion factor) (Gegg et al. 2010; Poole et al. 2010; Tanaka et al. 2010; Ziviani et al. 2010), Bcl-2 (Chen et al. 2010), and Drp1 (Wang et al. 2011) have thus far been shown to be ubiquitinated by Parkin. These ubiquitinated proteins may recruit the autophagy adaptor p62 (Ding et al. 2010; Geisler et al. 2010; Lee et al. 2010). However, the role of p62 remains controversial; p62 seems to be essential for mitochondrial clustering at the perinuclear region rather than for mitophagy itself (Narendra et al. 2010b; Okatsu et al. 2010). We also found that LC3-p62 interaction is not the first recognition step of damaged mitochondria, and upstream Atg proteins can be recruited in an LC3-independent manner (E Itakura and N Mizushima, unpubl. results).

More recently, Parkin was shown to also mediate proteasome-dependent degradation of a wide range of outer mitochondrial membrane proteins (Tanaka et al. 2010; Chan et al. 2011; Yoshii et al. 2011). In Parkinoverexpressing cells, loss of mitochondrial potential 
induces recruitment of the proteasome (Chan et al. 2011; Yoshii et al. 2011) and p97/VCP (Tanaka et al. 2010) to mitochondria. However, whether or not proteasomal degradation of outer membrane proteins is required for mitophagy remains controversial. We observed that inhibition of the proteasome does not affect mitophagy, suggesting that Parkin has two independent functions: turnover of outer membrane proteins at a molecular level, and turnover of entire mitochondria at the organelle level (Yoshii et al. 2011). On the other hand, Youle's and Chan's groups found that degradation of the outer membrane proteins contributes to mitophagy (Tanaka et al. 2010; Chan et al. 2011). Ubiquitination and degradation of mitofusin may affect mitochondrial fusion, which would facilitate mitophagy, even though mitofusin itself is not essential for mitophagy (Tanaka et al. 2010).

\section{AUTOPHAGY AND TUMORIGENESIS}

It has been suggested that autophagy is a tumor suppressor (Levine and Kroemer 2008; Chen and Debnath 2010; White et al. 2010). White's group has suggested several tumor-suppressive mechanisms: (1) suppression of tumorigenic inflammation (Degenhardt et al. 2006), (2) mitigation of metabolic stress and genomic damage (Karantza-Wadsworth et al. 2007; Mathew et al. 2007), and (3) degradation of tumorigenic p62 (Mathew et al. 2009). However, results from in vivo models have been limited. Beclin 1 heterozygous mutant mice show an increased frequency of spontaneous cancers in the lung, liver, and lymphoid tissues (Qu et al. 2003; Yue et al. 2003). Moreover, Beclin 1-interacting proteins such as Ambra 1 (Fimia et al. 2007), Bif-1 (Takahashi et al. 2007), and UVRAG (Liang et al. 2006) have also been shown to play a role in tumor suppression. However, these factors are not strictly specific for autophagy; they also function in the endocytic pathway (Funderburk et al. 2010; He and Levine 2010; Thoresen et al. 2010).

Systemic deletion of most Atg genes causes neonatal lethality and tissue-specific (e.g., brain and liver) autophagy-deficient mice are also often short-lived, which makes it difficult to evaluate the involvement of autophagy in vivo. To overcome these limitations, we generated a novel mouse model with systemic mosaic deletion of Atg5, in which only $10 \%-40 \%$ of cells show Atg5 gene deletion (Takamura et al. 2011). These mice develop multiple benign tumors in the liver, but not in other tissues (Fig. 3). In tumor cells, mitochondria are swollen and oxidative stress and genomic damage responses are promoted, suggesting the importance of mitochondrial quality control in tumor suppression.

Liver-specific Atg7-deficient mice also develop liver tumors (Takamura et al. 2011). Of importance, concomitant deletion of $\mathrm{p} 62$ reduces the size of the liver tumors, although it does not completely suppress tumor formation (Takamura et al. 2011). Thus, accumulation of p62 caused by autophagy deficiency may contribute to tumor progression, rather than tumorigenesis. These results



Figure 3. Tumors formed in Atg5 mosaically deleted mice. Liver tumors are formed in mice with mosaic deletion of the ATG5 gene (at $19 \mathrm{mo}$ ).

suggest that turnover of both proteins and organelles is critically important for prevention of spontaneous tumorigenesis and subsequent tumor progression.

\section{CONCLUSIONS}

As discussed above, the field of autophagy research has expanded very rapidly in recent years. It is now apparent that autophagy is linked to a large number of physiological processes in many organisms. It is, therefore, reasonable to assume that autophagy also plays a role in human diseases. In addition to the Parkin/PINK1 involvement in $\mathrm{PD}$, Atg16L1 has been reported to be associated with Crohn's disease, a chronic inflammatory bowel disease (Stappenbeck et al. 2010). It is likely that there are more human diseases in which autophagy defects could be pathogenic or in which autophagy could be a therapeutic target. The novel findings discussed in this chapter will aid further development of autophagy research in both basic and clinical fields.

\section{ACKNOWLEDGMENT}

This work was supported in part by Grants-in-Aid for Scientific Research from the Ministry of Education, Culture, Sports, Science and Technology, Japan, the Takeda Science Foundation, and the Funding Program for Next Generation World-Leading Researchers.

\section{REFERENCES}

Abou-Sleiman PM, Muqit MM, Wood NW. 2006. Expanding insights of mitochondrial dysfunction in Parkinson's disease. Nat Rev Neurosci 7: 207-219.

Bjørkøy G, Lamark T, Brech A, Outzen H, Perander M, Øvervatn A, Stenmark H, Johansen T. 2005. p62/SQSTM1 forms protein aggregates degraded by autophagy and has a protective effect on huntingtin-induced cell death. J Cell Biol 171: 603-614.

Cecconi F, Levine B. 2008. The role of autophagy in mammalian development: Cell makeover rather than cell death. Dev Cell 15: 344-357. 
Chan NC, Salazar AM, Pham AH, Sweredoski MJ, Kolawa NJ, Graham RL, Hess S, Chan DC. 2011. Broad activation of the ubiquitin-proteasome system by Parkin is critical for mitophagy. Hum Mol Genet 20: 1726-1737.

Chen N, Debnath J. 2010. Autophagy and tumorigenesis. FEBS Lett 584: 1427-1435.

Chen D, Gao F, Li B, Wang H, Xu Y, Zhu C, Wang G. 2010. Parkin mono-ubiquitinates BCL-2 and regulates autophagy. J Biol Chem 285: 38214-38223.

Degenhardt K, Mathew R, Beaudoin B, Bray K, Anderson D, Chen G, Mukherjee C, Shi Y, Gelinas C, Fan Y, et al. 2006. Autophagy promotes tumor cell survival and restricts necrosis, inflammation, and tumorigenesis. Cancer Cell 10: $51-64$.

Ding WX, Ni HM, Li M, Liao Y, Chen X, Stolz DB, Dorn Ii GW, Yin XM. 2010. Nix is critical to two distinct phases of mitophagy: Reactive oxygen species (ROS)-mediated autophagy induction and Parkin-ubiquitin-p62-mediated mitochondria priming. J Biol Chem 285: 27879-27890.

Fimia GM, Stoykova A, Romagnoli A, Giunta L, Di Bartolomeo S, Nardacci R, Corazzari M, Fuoco C, Ucar A, Schwartz P, et al. 2007. Ambra1 regulates autophagy and development of the nervous system. Nature 447: 1121-1125.

Funderburk SF, Wang QJ, Yue Z. 2010. The Beclin 1-VPS34 complex-At the crossroads of autophagy and beyond. Trends Cell Biol 20: 355-362.

Gegg ME, Cooper JM, Chau KY, Rojo M, Schapira AH, Taanman JW. 2010. Mitofusin-1 and Mitofusin-2 are ubiquitinated in a PINK1/parkin dependent manner upon induction of mitophagy. Hum Mol Genet 19: 4861-4870.

Geisler S, Holmstrom KM, Skujat D, Fiesel FC, Rothfuss OC, Kahle PJ, Springer W. 2010. PINK1/Parkin-mediated mitophagy is dependent on VDAC1 and p62/SQSTM1. Nat Cell Biol 12: 119-131.

Hara T, Nakamura K, Matsui M, Yamamoto A, Nakahara Y, Suzuki-Migishima R, Yokoyama M, Mishima K, Saito I, Okano H, et al. 2006. Suppression of basal autophagy in neural cells causes neurodegenerative disease in mice. Nature 441: $885-889$.

He C, Levine B. 2010. The Beclin 1 interactome. Curr Opin Cell Biol 22: 140-149.

Karantza-Wadsworth V, Patel S, Kravchuk O, Chen G, Mathew R, Jin S, White E. 2007. Autophagy mitigates metabolic stress and genome damage in mammary tumorigenesis. Genes Dev 21: $1621-1635$.

Kawajiri S, Saiki S, Sato S, Sato F, Hatano T, Eguchi H, Hattori N. 2010. PINK1 is recruited to mitochondria with parkin and associates with LC3 in mitophagy. FEBS Lett 584: $1073-1079$

Kim PK, Hailey DW, Mullen RT, Lippincott-Schwartz J. 2008. Ubiquitin signals autophagic degradation of cytosolic proteins and peroxisomes. Proc Natl Acad Sci 105: $20567-$ 20574

Kirkin V, McEwan DG, Novak I, Dikic I. 2009. A role for ubiquitin in selective autophagy. Mol Cell 34: 259-269.

Kitada T, Asakawa S, Hattori N, Matsumine H, Yamamura Y, Minoshima S, Yokochi M, Mizuno Y, Shimizu N. 1998. Mutations in the parkin gene cause autosomal recessive juvenile parkinsonism. Nature 392: 605-608.

Komatsu M, Waguri S, Ueno T, Iwata J, Murata S, Tanida I, Ezaki J, Mizushima N, Ohsumi Y, Uchiyama Y, et al. 2005. Impairment of starvation-induced and constitutive autophagy in Atg7-deficient mice. $J$ Cell Biol 169: 425-434.

Komatsu M, Waguri S, Chiba T, Murata S, Iwata JI, Tanida I, Ueno T, Koike M, Uchiyama Y, Kominami E, et al. 2006. Loss of autophagy in the central nervous system causes neurodegeneration in mice. Nature 441: 880-884.

Komatsu M, Waguri S, Koike M, Sou YS, Ueno T, Hara T, Mizushima N, Iwata JI, Ezaki J, Murata S, et al. 2007. Homeostatic levels of p62 control cytoplasmic inclusion body formation in autophagy-deficient mice. Cell 131: 1149-1163.
Komatsu M, Kurokawa H, Waguri S, Taguchi K, Kobayashi A, Ichimura Y, Sou YS, Ueno I, Sakamoto A, Tong KI, et al. 2010. The selective autophagy substrate p62 activates the stress responsive transcription factor Nrf2 through inactivation of Keap1. Nat Cell Biol 12: 213-223.

Kraft C, Peter M, Hofmann K. 2010. Selective autophagy: Ubiquitin-mediated recognition and beyond. Nat Cell Biol 12: $836-841$.

Kuma A, Hatano M, Matsui M, Yamamoto A, Nakaya H, Yoshimori T, Ohsumi Y, Tokuhisa T, Mizushima N. 2004. The role of autophagy during the early neonatal starvation period. Nature 432: $1032-1036$.

Lau A, Wang XJ, Zhao F, Villeneuve NF, Wu T, Jiang T, Sun Z, White E, Zhang DD. 2010. A non-canonical mechanism of Nrf2 activation by autophagy deficiency: A direct interaction between Keap1 and p62. Mol Cell Biol 30: 3275-3285.

Lee JY, Nagano Y, Taylor JP, Lim KL, Yao TP. 2010. Diseasecausing mutations in Parkin impair mitochondrial ubiquitination, aggregation, and HDAC6-dependent mitophagy. J Cell Biol 189: 671-679.

Levine B, Kroemer G. 2008. Autophagy in the pathogenesis of disease. Cell 132: 27-42.

Levine B, Mizushima N, Virgin HW. 2011. Autophagy in immunity and inflammation. Nature 469: 323-335.

Liang C, Feng P, Ku B, Dotan I, Canaani D, Oh BH, Jung JU. 2006. Autophagic and tumour suppressor activity of a novel Beclin1-binding protein UVRAG. Nat Cell Biol 8: 688-699.

Longatti A, Tooze SA. 2009. Vesicular trafficking and autophagosome formation. Cell Death Differ 16: 956-965.

Mathew R, Kongara S, Beaudoin B, Karp CM, Bray K, Degenhardt K, Chen G, Jin S, White E. 2007. Autophagy suppresses tumor progression by limiting chromosomal instability. Genes Dev 21: 1367-1381.

Mathew R, Karp CM, Beaudoin B, Vuong N, Chen G, Chen HY, Bray K, Reddy A, Bhanot G, Gelinas C, et al. 2009. Autophagy suppresses tumorigenesis through elimination of $\mathrm{p} 62$. Cell 137: 1062-1075.

Matsuda N, Sato S, Shiba K, Okatsu K, Saisho K, Gautier CA, Sou YS, Saiki S, Kawajiri S, Sato F, et al. 2010. PINK1 stabilized by mitochondrial depolarization recruits Parkin to damaged mitochondria and activates latent Parkin for mitophagy. J Cell Biol 189: 211-221.

Mizushima N. 2007. Autophagy: Process and function. Genes Dev 21: $2861-2873$.

Mizushima N, Levine B. 2010. Autophagy in mammalian development and differentiation. Nat Cell Biol 12: 823-830.

Mizushima N, Levine B, Cuervo AM, Klionsky DJ. 2008. Autophagy fights disease through cellular self-digestion. Nature 451: 1069-1075.

Moscat J, Diaz-Meco MT. 2009. p62 at the crossroads of autophagy, apoptosis, and cancer. Cell 137: 1001-1004.

Myeku N, Figueiredo-Pereira ME. 2011. Dynamics of the degradation of ubiquitinated proteins by proteasomes and autophagy: Association with sequestosome 1/p62. J Biol Chem 286: $22426-22440$.

Narendra D, Tanaka A, Suen DF, Youle RJ. 2008. Parkin is recruited selectively to impaired mitochondria and promotes their autophagy. J Cell Biol 183: 795-803.

Narendra DP, Jin SM, Tanaka A, Suen DF, Gautier CA, Shen J, Cookson MR, Youle RJ. 2010a. PINK1 is selectively stabilized on impaired mitochondria to activate Parkin. PLoS Biol 8: e1000298.

Narendra DP, Kane LA, Hauser DN, Fearnley IM, Youle RJ. 2010b. p62/SQSTM1 is required for Parkin-induced mitochondrial clustering but not mitophagy; VDAC1 is dispensable for both. Autophagy 6: 1090-1106.

Okatsu K, Saisho K, Shimanuki M, Nakada K, Shitara H, Sou YS, Kimura M, Sato S, Hattori N, Komatsu M, et al. 2010. p62/SQSTM1 cooperates with Parkin for perinuclear clustering of depolarized mitochondria. Genes Cells 15: 887-900.

Onodera J, Ohsumi Y. 2005. Autophagy is required for maintenance of amino acid levels and protein synthesis under nitrogen starvation. J Biol Chem 280: 31582-31586. 
Pankiv S, Hoyvarde Clausen T, Lamark T, Brech A, Bruun JA, Outzen H, Øvervatn A, Bjørkøy G, Johansen T. 2007. p62/ SQSTM1 binds directly to Atg8/LC3 to facilitate degradation of ubiquitinated protein aggregates by autophagy. J Biol Chem 282: 24131-24145.

Poole AC, Thomas RE, Yu S, Vincow ES, Pallanck L. 2010. The mitochondrial fusion-promoting factor mitofusin is a substrate of the PINK1/Parkin pathway. PLoS One 5: e10054.

Qu X, Yu J, Bhagat G, Furuya N, Hibshoosh H, Troxel A, Rosen J, Eskelinen E-L, Mizushima N, Ohsumi Y, et al. 2003. Promotion of tumorigenesis by heterozygous disruption of the beclin 1 autophagy gene. J Clin Invest 112: 1809-1820.

Rakovic A, Grunewald A, Seibler P, Ramirez A, Kock N, Orolicki S, Lohmann K, Klein C. 2010. Effect of endogenous mutant and wild-type PINK1 on Parkin in fibroblasts from Parkinson disease patients. Hum Mol Genet 19: 3124-3137.

Riley BE, Kaiser SE, Shaler TA, Ng AC, Hara T, Hipp MS, Lage K, Xavier RJ, Ryu KY, Taguchi K, et al. 2010. Ubiquitin accumulation in autophagy-deficient mice is dependent on the Nrf2-mediated stress response pathway: A potential role for protein aggregation in autophagic substrate selection. $J$ Cell Biol 191: 537-552.

Rubinsztein DC. 2006. The roles of intracellular protein-degradation pathways in neurodegeneration. Nature 443: 780-786.

Seibenhener ML, Geetha T, Wooten MW. 2007. Sequestosome 1/p62 - more than just a scaffold. FEBS Lett 581: 175-179.

Sou YS, Waguri S, Iwata J, Ueno T, Fujimura T, Hara T, Sawada N, Yamada A, Mizushima N, Uchiyama Y, et al. 2008. The Atg8 conjugation system is indispensable for proper development of autophagic isolation membranes in mice. Mol Biol Cell 19: 4762-4775.

Stappenbeck TS, Rioux JD, Mizoguchi A, Saitoh T, Huett A, Darfeuille-Michaud A, Wileman T, Mizushima N, Carding S, Akira S, et al. 2010. Crohn disease: A current perspective on genetics, autophagy and immunity. Autophagy 7:355-374.

Suzuki K, Ohsumi Y. 2007. Molecular machinery of autophagosome formation in yeast, Saccharomyces cerevisiae. FEBS Lett 581: 2156-2161.

Suzuki SW, Onodera J, Ohsumi Y. 2011. Starvation induced cell death in autophagy-defective yeast mutants is caused by mitochondria dysfunction. PLoS One 6: e17412.

Takahashi Y, Coppola D, Matsushita N, Cualing HD, Sun M, Sato Y, Liang C, Jung JU, Cheng JQ, Mul JJ, et al. 2007. Bif-1 interacts with Beclin 1 through UVRAG and regulates autophagy and tumorigenesis. Nat Cell Biol 9: 1142-1151.

Takamura A, Komatsu M, Hara T, Sakamoto A, Kishi C, Waguri S, Eishi Y, Hino O, Tanaka K, Mizushima N. 2011. Autophagy-deficient mice develop multiple liver tumors. Genes Dev 25: 795-800.
Tanaka A, Cleland MM, Xu S, Narendra DP, Suen DF, Karbowski M, Youle RJ. 2010. Proteasome and p97 mediate mitophagy and degradation of mitofusins induced by Parkin. J Cell Biol 191: 1367-1380.

Thoresen SB, Pedersen NM, Liestol K, Stenmark H. 2010. A phosphatidylinositol 3-kinase class III sub-complex containing VPS15, VPS34, Beclin 1, UVRAG and BIF-1 regulates cytokinesis and degradative endocytic traffic. Exp Cell Res 316: $3368-3378$.

Tsukada M, Ohsumi Y. 1993. Isolation and characterization of autophagy-defective mutants of Saccharomyces cerevisiae. FEBS Lett 333: 169-174.

Tsukamoto S, Kuma A, Murakami M, Kishi C, Yamamoto A, Mizushima N. 2008. Autophagy is essential for preimplantation development of mouse embryos. Science 321: 117-120.

Vives-Bauza C, Zhou C, Huang Y, Cui M, de Vries RL, Kim J, May J, Tocilescu MA, Liu W, Ko HS, et al. 2010. PINK1dependent recruitment of Parkin to mitochondria in mitophagy. Proc Natl Acad Sci 107: 378-383.

Wang H, Song P, Du L, Tian W, Yue W, Liu M, Li D, Wang B, Zhu Y, Cao C, et al. 2011. Parkin ubiquitinates Drp1 for proteasome-dependent degradation: Implication of dysregulated mitochondrial dynamics in Parkinson's disease. J Biol Chem 286: 11649-11658.

White E, Karp C, Strohecker AM, Guo Y, Mathew R. 2010. Role of autophagy in suppression of inflammation and cancer. Curr Opin Cell Biol 22: 212-217.

Wooten MW, Hu X, Babu JR, Seibenhener ML, Geetha T, Paine MG, Wooten MC. 2006. Signaling, polyubiquitination, trafficking, and inclusions: Sequestosome 1/p62's role in neurodegenerative disease. J Biomed Biotechnol 2006: 1-12.

Xie Z, Klionsky DJ. 2007. Autophagosome formation: Core machinery and adaptations. Nat Cell Biol 9: 1102-1109.

Yoshii SR, Kishi C, Ishihara N, Mizushima N. 2011. Parkin mediates proteasome-dependent protein degradation and rupture of the outer mitochondrial membrane. J Biol Chem 286: 19630-19640.

Youle RJ, Narendra DP. 2011. Mechanisms of mitophagy. Nat Rev Mol Cell Biol 12: 9-14.

Yue Z, Jin S, Yang C, Levine AJ, Heintz N. 2003. Beclin 1, an autophagy gene essential for early embryonic development, is a haploinsufficient tumor suppressor. Proc Natl Acad Sci 100: 15077-15082.

Zhu J, Chu CT. 2010. Mitochondrial dysfunction in Parkinson's disease. J Alzheimers Dis 2 (20 suppl): S325-S334.

Ziviani E, Tao RN, Whitworth AJ. 2010. Drosophila Parkin requires PINK1 for mitochondrial translocation and ubiquitinates mitofusin. Proc Natl Acad Sci 107: 5018-5023. 


\section{$\$_{\text {CSH\& }}^{\infty}$ Cold Spring Harbor Symposia SYMPOSIA On Quantitative Biology}

\section{Autophagy in Protein and Organelle Turnover}

N. Mizushima

Cold Spring Harb Symp Quant Biol 2011 76: 397-402 originally published online August 3, 2011 Access the most recent version at doi:10.1101/sqb.2011.76.011023

References This article cites 71 articles, 25 of which can be accessed free at: http://symposium.cshlp.org/content/76/397.full.html\#ref-list-1

\section{License}

Email Alerting Receive free email alerts when new articles cite this article - sign up in Service the box at the top right corner of the article or click here. 